\title{
Conceptualising Responses to Institutional Abuse of Children
}

\author{
Kathleen Daly*
}

\begin{abstract}
Institutional abuse of children was 'discovered' in the 1980s, with concept diffusion in the 1990s. I explain why it emerged as a social problem and what factors triggered a response by authorities that 'something must be done' to address it. Some have argued that the 1980s was a time of a 'moral panic' about child sexual abuse, in particular, that fears of abuse were exaggerated and misdirected. Drawing from 19 major cases in Canada and Australia and those in other countries, I find that a moral panic analysis is not apt in understanding responses to institutional abuse. Although concern with sexual and physical abuse of children was important, additional factors motivated government and church officials to respond; and in some cases, child abuse was secondary to other identified wrongs against children. I identify distinctive types of institutional abuse cases, the 'core' and the 'core-plus' cases, which moved into the public arena for different reasons and in different ways. Implications are drawn for comparative research and theoretical developments in the area.
\end{abstract}

Keywords: child sexual abuse - institutional abuse - redress - social problems - moral panic - transitional justice - Australia - Canada - Wales

Responses to institutional abuse of children constitute a 'new interdisciplinary field' of knowledge (Sköld 2013:7), prompted by a plethora of public inquiries, civil litigation, and redress schemes from the 1990s onward. The first public inquiry to focus on institutional abuse of children', as a named social problem, was conducted in the United States (US) (1979 Senate Hearings on Abuse and Neglect of Children in Institutions). Other inquiries were established in the 1980s and 1990s in England and Wales, Northern Ireland, Canada, and Australia. Since 2000, many more national inquiries, redress schemes, and related responses have been launched or completed in Australia, Belgium, Canada, Denmark, England and Wales, Finland, Germany, Iceland, Ireland, the Netherlands, New Zealand, Northern Ireland, Norway, Scotland, Sweden, and the US. Clearly, something is happening.

When I began this research in 2010, there were many angles to explore, different disciplinary questions to answer and theoretical avenues to pursue, and varied country- or region-specific historical contexts to consider. My initial interest was to identify innovative

Professor of Criminology and Criminal Justice, Griffith University. Correspondence: School of Criminology and Criminal Justice, Mt Gravatt Campus, Griffith University, QLD 4111, Australia. This research was supported by two Australian Research Council Grants (DP 0879691, 2008-11; and DP130103775, 2013-15). 
justice responses to 19 major Canadian and Australian case studies of historical institutional abuse of children. ${ }^{1}$ In time, I began to ask new questions. Why, did institutional abuse emerge as a social problem? What sparked a response by relevant authorities that something should be done to address it?

This article presents one piece of a larger project that historicises institutional abuse, presents survivors' memories of institutional life, and analyses redress processes and outcomes (Daly 2014). It outlines evolving developments that gave rise to responses to institutional abuse in Australia, Canada, and other countries; and in doing so, identifies distinctive types of cases. The next section of the article defines institutional abuse, introduces the sample cases, and describes a typology of cases. By a 'case', I do not mean a legal case; rather, I mean a case study of the history of the institution (or policy and practice) and responses to it. The article then analyses the emergence of institutional abuse as a social problem and what sparked responses to it. By a 'response', I mean the initial and subsequent responses of an authority (typically, a government or church entity) to address a perceived social problem. The final section reflects on theoretical developments in the area.

\section{Definitions and cases}

\section{What is institutional abuse?}

The social problem of institutional abuse of children is not self-evident: it depends on what is defined as 'institutional' and as 'abuse'. The analysis in this article centres on historical abuse in residential care facilities, not community-based institutions (the latter includes schools, clubs, and religious and sports associations for children and youth). However, since 2000, some have argued for widening the term 'institutional' to include non-family community-based contexts of victimisation. Including these contexts is a consequence, in part, of the decreasing reliance on large residential care facilities for children in affluent nations (although the reverse is occurring elsewhere in the world due to poverty and displacement: see Csáky 2009). It is also a consequence of an increased focus on sexual victimisation of children in non-family settings. Thus, today, institutional abuse of children is constructed in at least three ways: sexual abuse of children by adults in a range of residential care and community-based settings; physical, sexual, or emotional abuse of children by adults (or their peers) in residential and out-of-home care; and, most broadly, the conditions of life in the 'dehumanising institutional environment' of residential care (Penglase 2005:48). The latter is concerned with regimes of 'care', not specific acts of abuse. Adding further complexity, institutional abuse can refer to historical or contemporary abuse or to both. ${ }^{2}$

If the focus of analysis is on historical institutional abuse, abuse is broadly construed as physical, sexual, emotional, and in some instances, cultural; and the types of institutions considered are 'total' (or not-so-total) in that they are segregated from the mainstream of society. By comparison, if the focus is on contemporary institutional abuse, institutions are broadly construed to include residential facilities, out-of-home care, and any organised activity outside the family home; however, attention often centres on sexual abuse. Thus, in

\footnotetext{
'Children', 'boys' and 'girls' includes those up to 17-19 years of age, depending on the jurisdiction. 'Institutional abuse' refers to abuse occurring against children living in institutions (orphanages, homes, farms, training schools, residential schools, hostels, and youth detention) or in out-of-home care (foster care and foster homes).

2 The literature on institutional abuse is not confined to children as victims or survivors, but also includes adults living in residential facilities (Stanley, Manthorpe and Penhale 1999).
} 
general, the literature on historical institutional abuse deals with residential institutions for children in the past, and with adult survivors seeking recognition and redress, whereas that on contemporary institutional abuse is concerned with mapping the prevalence of sexual abuse in a wide variety of settings and identifying modes of intervention and prevention.

\section{The sample of cases and types of cases}

The sample of 19 cases comprises all the major Canadian and Australian cases of historical institutional abuse of children in residential care, ${ }^{3}$ which came to public attention by mid-2010. ${ }^{4}$

The response to institutional abuse can be conceptualised as a core with two concentric rings. Common to all cases, the 'core', is a failure of government or church authorities to protect and care for children. Of the 19 cases, 12 are 'core' cases in that this was the sole basis for the response. Five are 'core-plus' cases. In these, policy or practice wrongs were committed against certain groups of children ('core-plus-one' cases), or the wrongs against children were embedded in a more general discrimination against a group ('core-plus-two' cases). In the core-plus cases, allegations of (and convictions for) institutional abuse were relevant, but secondary, to the policy or practice wrongs against children. The remaining two cases are redress schemes only: they addressed failures of government and church authorities in the core and core-plus cases. As this article will show, the core-plus cases moved in the public arena in different ways and for different reasons than the core cases. They have a large cultural platform of books, television series, films, and oral history projects, which advanced political campaigns and social movement activism and educated the general public about the history of policy wrongs against children and political minority groups.

The Appendix lists each case with relevant descriptive information. Although this article analyses only some of the cases, it is helpful to see the entire sample. Column (1) gives the case number and column (2), the shortened case name (in italics) and type of case (core, coreplus-one, core-plus-two, redress scheme only). The Canadian core-plus-one cases are Alberta Sterilisation (involuntary sterilisation of those with mental disabilities, who resided in mental hospitals) and Duplessis Orphans (falsely classifying children as mentally defective or wrongfully placing them in psychiatric institutions). The Australian core-plus-one case is Child Migrants (British and Australian governments' joint policies of removing British children from families and sending them to receiving institutions in Australia, ${ }^{5}$ often without parental knowledge or consent). The core-plus-two cases are Indian Residential Schools (the Canadian Government's policy of forcible assimilation of Native children by their removal from families and attendance at residential schools) and Stolen Generations (all Australian jurisdictions' legislation that permitted practices of forcible assimilation of certain Indigenous children by their removal from families and placement in institutions or foster care).

3 Five included both residential and out-of-home care, as determined by the case actors.

4 For Canada, two cases since mid- 2010 are Huronia Regional Center and Nova Scotia Home for Coloured Children. For Australia, five cases since mid-2010 were launched or concluded: an inquiry into and redress scheme for abuse in Western Australian country hostels; state inquiries into child abuse in religious organisations (Victoria) and in state care (Queensland); police investigations of child sexual abuse in a Catholic diocese (New South Wales), and the Australian Government's Royal Commission into Institutional Responses to Child Sexual Abuse.

5 British children were also sent to Canada, the Caribbean, New Zealand, Rhodesia, South Africa, and the US (Australian Senate Community Affairs References Committee 2001:13). Child migrants were drawn from those in state care; their parents may have been too poor to care for them, their mothers were unmarried, or they were orphaned (for greater detail, see the report of the Australian Senate Affairs References Committee 2001:36-7, 53-5). A smaller number of Maltese children were sent to Australia, but their parents voluntarily consented to the migration. 
The longer case name and location of institution are shown in columns (3) and (4); and the types of institutions, in column (5). Five of the 19 cases included foster placements (all Australian). ${ }^{6}$ Column (6) shows more sources of variability. Most cases concerned sexual and physical abuse (some also included neglect), but four were of sexual abuse only. Column (7) shows the number of institutions or children affected.

Column (8) gives the response start year and the type of response. Of the 19 cases, the initial response was a public inquiry (seven cases) or a police or other type of investigation (eight cases). Four had another type of response: two began with a redress scheme, and two were government responses to significant civil litigation. Although several factors often trigger a response, those I saw as the most relevant in each case were identified. The triggering factors were victims' complaints to authorities (five cases), media stories (six cases), advocacy campaigns (four cases), civil litigation (two cases), and preceding inquiries (two cases). As each case evolved, other actions or activities emerged such as criminal prosecution and conviction, civil litigation, and the creation of redress schemes; together these constitute the overall response. Indicative outcomes are also given in column (8) (see Daly 2014 for further analysis of redress structure, process, and outcomes). Before analysing responses and what sparked them, I consider why institutional abuse of children emerged as a social problem.

\section{Discovering institutional abuse}

Institutional abuse of children was 'discovered' in the 1980s. It built upon the 'discovery' of child physical abuse in the 1960s, with an article by Kempe and colleagues (1962) on 'the battered child syndrome'. Concept diffusion - that is, seeing child physical abuse as widespread - occurred in the late 1960s and early 1970s (Parton 1979). The 'discovery' of child sexual abuse began in the 1970s. During this time, second-wave feminism brought sexual victimisation of children and women to public attention, although child-saving workers in the $19^{\text {th }}$ century were well aware of the problem (Gordon 1988). The next step of seeing child sexual abuse as widespread - began in the 1970s and continued into the 1980s. Like child physical abuse, attention centred on intrafamilial sexual abuse.

The term 'institutional abuse' of children was coined by David Gil (1975), who defined it broadly to include not only acts of abuse, but also 'abusive conditions' and policies (Gil 1975:347). This broad conceptualisation began to narrow when the US Government funded pilot projects on institutional child abuse in the late 1970s. An early finding by Eliana Gil and Kathleen Baxter (1979:693) was the denial of abuse by the administrators of care facilities. Some "remembered "vague rumours" of a particular staff member physically or sexually abusing a child', but none believed that 'abusive behaviour' by their staff toward children 'was a potential or existing problem' (Gil and Baxter 1979:694).

Up until the 1980s, physical abuse of children in institutions was termed 'cruelty', 'mistreatment', or 'harsh discipline'. From the mid- $19^{\text {th }}$ century to 1970 , there had been many inquiries and investigations in Canada, Australia, and elsewhere of child maltreatment and the negative effects of institutions on children. Individual offending was sometimes prosecuted and resulted in convictions. However, institutional practices did not change. In Canada and Australia, this was because funding arrangements between the state and religious or charitable organisations made it difficult to enforce regulations, officials

$6 \quad$ Although a sixth Australian case (Forgotten Australians) initially included foster care, it was the subject of a second Senate report: Australian Senate Community Affairs References Committee (2004). 
deferred to religious and medical authorities, authorities were unable to 'see' abuse, and institutional carers were successful in concealing injuries or giving 'the impression of adequate care' when inspections were carried out (Ferguson 2007:128).

This changed in the 1980s, although it had been building from the 1960s. The reasons for the shift are four-fold: (1) changing concepts of childhood; (2) new concepts that facilitated 'seeing' abuse; (3) celebrated media cases of clergy sexual abuse; and (4) a 'sexual turn' in the institutional abuse story. As Corby, Doig and Roberts (2001:43) suggest, beginning in the 1960s, there was a shift toward a more child-centred world, a 'prizing of childhood', which came about with increasing affluence, higher standards of living, lower birth rates, and better treatment of child illnesses. New concepts of child physical and sexual abuse, introduced in the 1960s and 1970s, facilitated the ability for parents or family members, residential staff, social workers, and medical staff to 'see' institutional abuse in the 1980s. Major cases of clergy abuse first came to notoriety in the US in 1984, with media stories about Gilbert Gauthe's sexual abuse of boys. Gauthe's offending, like that of other priests, took place outside care facilities for children (Lytton 2008:1). However, Gauthe's and other priests' admissions of sexual offending made more 'thinkable' and 'credible' children's reports of sexual abuse by members of religious orders within residential care settings. ${ }^{8}$

\section{The 'sexual turn'}

A strong belief by authorities and the general public that 'something must be done' to address institutional abuse can be traced to what I call the 'sexual turn' in the story. Three factors were at play. First, children were alleging that the abuse was sexual; it was not harsh physical regimes or corporal punishment, for which 'there was a fair degree of acceptance' of its use in care settings. By contrast, sexual abuse was 'a more disturbing form of abuse' (Corby, Doig and Roberts 2001:83), which could not be easily brushed aside as discipline. Here, it should be noted that boys had reported 'indecent practices' committed against them by male residential staff, as early as the 1950s in England and Wales and in Canada. For England and Wales, Rollinson (2006:24) suggests that those receiving the boys' reports 'could well have been struggling ... to regard such acts ... as anything other than unthinkable and unspeakable'. For Canada, department officials thought that much of what the boys said was 'exaggeration', and they were 'reluctant to believe all they had heard' (Hoffman 1996:93). Second, when cases of sexual abuse in residential care first emerged publicly in Northern Ireland, Canada, and England and Wales, beginning in 1980 and to the early 1990s, there seemed to be 'constant stream of revelations', which raised questions about 'why it was apparently so prevalent' (Corby, Doig and Roberts 2001:87). Third, and related, sexual abuse became 'observable'. As Pratt (2009:70) suggests, citing Hacking (1998:82), a social problem must be 'strange, disturbing and noticed' (emphasis in original). It must have a 'quantifiable element' and be 'newsworthy as well' (Pratt 2009:70). For Canada, this occurred in 1982 with estimates of prevalence in Toronto, which were re-estimated in the Badgley Report (1984). The estimates were not solely of sexual abuse of

7 Precise years of social problem definition vary: the US was somewhat earlier than Australia, Canada, and the United Kingdom (UK) in the discovery and diffusion of child abuse as a social problem. For institutional abuse of children in England and Wales, Corby, Doig and Roberts (2001:47) suggest that 'concerns ... had taken hold by 1990'.

8 There had been criminal prosecutions of priests in the US in the $19^{\text {th }}$ century, and civil litigation decades before and during civil litigation against Gauthe. However, his case became a major focus of national attention, and together with other cases in the US, 'it created the impression of a pervasive, nationwide problem' (Lytton 2008:11). 
children in institutions, but sexual abuse of children and youth more generally in Canada. However, 'as the problem became more observable, so there was an escalation in reported cases' (Pratt 2009:72) in both non-institutional and institutional settings.

A crucial factor in observability was adult survivors' firsthand accounts of abuse. Davis (2005:27) argues that up to 1970, 'standing up in public and telling a personal story of childhood molestation was a revolutionary thing to do'. There had been survey research on sexual experiences as early as the 1920 s, as well as clinical assessments, but 'first person public accounts ... outside a legal context were non-existent' (Davis 2005:27). Davis (2005:28) argues that up to 1971, when Florence Rush spoke publicly of being sexually victimised as a child, 'there were no public victim stories because there was no collective victimization story'. In the early-1970s, Rush's public victim story was of intrafamilial sexual abuse of girls by men. By the mid- to late-1980s, there was a new public victim story: institutional sexual abuse of boys by men.

\section{Responding to institutional abuse}

\section{Triggering factors: What sparked a response?}

Is the discovery and intense concern with institutional abuse evidence of a 'moral panic'? When does 'public concern' with a social problem become a 'moral panic'? Garland (2008:11) draws from the moral panic literature to identify these elements: (1) concern (an 'event sparks anxiety'); (2) hostility toward a perpetrator; (3) consensus ('the negative social reaction is broad') (4) disproportionality (an exaggerated sense of threat); and (5) volatility (sudden emergence and dissipation 'of the media's reporting and the associated panic'). He further reflects on responses to child abuse as a social problem. Here he suggests a need to distinguish between responses that are attributed to 'panics' and those that are 'rational reactions to underlying problems' (Garland 2008:16). For child abuse, he proposes that an 'initial moral panic may ... force the problem onto the political agenda', but once the phenomenon is understood, the subsequent reaction is rational, not exaggerated (Garland 2008:16). Garland has in mind contemporary child sexual or physical abuse in community settings, not historical abuse in residential or out-of-home care. Are moral panics evident in historical abuse cases? Few have addressed this question, and the research is from England and Wales (for example, Corby, Doig and Roberts 2001; Webster 2005).

Corby, Doig and Roberts (2001) give a detailed analysis of the events leading up to the establishment of the North Wales Tribunal of Inquiry ('North Wales') in 1996. Their analysis attempts to relate evolving developments in an institutional abuse case to broader social currents of social problem 'discovery' and response. Distilling events, one sees a succession of early, but failed 'responses', which included investigations by the police and other independent units over a 10-year period, from 1986 onwards. These activities were incomplete or deemed unsatisfactory, which escalated demands to get 'to the bottom of the matter' and to 'know the truth' (Corby, Doig and Roberts 2001:97, 120). ${ }^{9}$ The authors argue that the Government 'had succumbed to pressures exerted by local politicians and campaigners in a climate where abuse of children in residential care was perceived as

The quest to 'know the truth' continues amid controversy surrounding publication of the inquiry report (Waterhouse 2000), with some arguing that the case was a moral panic and produced false allegations of abuse (Webster 2005). Others suggest, by comparison, that the scope of the Inquiry was too narrow. In 2012, the Macur Review was established to review the North Wales Inquiry and to determine if it failed to investigate relevant allegations of abuse of children in care in the two counties. The case has more years to run. 
widespread and unacceptable' (Corby, Doig and Roberts 2001:115). The specific triggering factors were sustained pressure from politicians and campaigners, sustained media coverage, and perceptions of a 'particularly pathological set of regimes', which 'indicated paedophile rings and widespread exposure of children to organised abuse' (Corby, Doig and Roberts 2001:119, emphasis added). Importantly, they identified public concern with perceived cover-ups by welfare authorities and the police as a crucial factor. Ultimately, they concluded that the inquiry was established 'to satisfy a public need to know the truth', particularly to know if alleged abuse was 'being covered up by the authorities possibly because they, or their officials, were party to the activities under investigation' (Corby, Doig and Roberts 2001:120). Thus, responses to institutional abuse may only partly be about abuse of children; they also include allegations of a failure of authorities to investigate the matter properly and their efforts to hide the truth from the public. This is a common theme in the Canadian and Australian core cases.

For Scandinavian countries, Arvidsson (2011:7) says that the flashpoint for the 2006 Swedish Inquiry on Child Abuse and Neglect in Institutions and Foster Homes was a television program in which men talked about their experiences of sexual and physical abuse in a boys' home in the 1950s and 1960s. Here we see that the response is an inquiry, and the triggering factor is victims' public stories of abuse in the media. Arvidsson adds that for some years preceding the television program, survivor groups 'had been fighting for recognition of wrongs done to them ... and had organized class actions against municipalities' (Arvidsson 2011:7). Thus, another factor is the role of victim advocacy in civil litigation. Sköld (2013:14) suggests that, in general, it was 'shocking revelations of abuse ... in television documentaries and other media' that brought institutional abuse to public attention in Sweden, Denmark, and Ireland. Thus, she places emphasis on 'shocking' media stories as the triggering factor. In Norway, however, she notes another set of concerns: the treatment of 'children of national minority groups' (Sköld 2013: 10). These include German soldiers' children born in Norway during the German occupation in World War II [and] assimilation politics involving Travellers and the Sami and Kvaeni peoples' (Sköld 2013:10). Moreover, she notes that recent attention has been paid in Sweden to 'the suffering and history of the Romani people', and in Denmark, to the forced removal of children in Greenland to Denmark (Sköld 2013:10). These latter examples are of core-plus cases, but Sköld does not say what triggered public concern about and attention to political minority groups.

\section{Types of cases, responses, and triggering factors}

The discussion below draws from the data in the Appendix (column 8) and relates the core/core-plus typology of institutional abuse cases to the initial responses and what triggered them. The initial response in the 12 core cases was a public inquiry or an investigation by the police or other authority. The initial response in the five core-plus cases was a public inquiry and government responses to major civil litigation. ${ }^{10}$ Differences emerge, as we might expect, in what triggered the response. In the core cases, it was victims' reports to authorities or media stories of sexual abuse. However, in the core-plus cases, responses were triggered by advocacy group campaigns and the press of civil litigation. I turn next to give examples.

10 Forgotten Australians is a difficult case to classify; although I call it a core case, it is typically grouped with two Australian core-plus cases (Stolen Generations and Child Migrants) as part of the trilogy of Commonwealth cases. 


\section{Mount Cashel: A Canadian core case}

The response to institutional abuse of children at Mount Cashel School for Boys in Newfoundland was the first such response in Canada.

On 13 February 1989, St John's radio host Bill Rowe received a caller to his morning talk show program. On air, the caller said that in a 1979 inquiry, testimony was given of a coverup in police investigations undertaken in 1975 into allegations of sexual and physical abuse of boys at Mount Cashel. That day, Katherine Caddigan, who had listened to the show, rang Robert Hyslop, the Associate Deputy Attorney General of the province. She demanded a public inquiry be conducted of cover-ups in the 1975 Mount Cashel investigation. Hyslop recalled that he had 'heard rumours' about Mount Cashel, but thought they were confined to 'strapping of children', for which charges had not been laid. He told Caddigan that he was unable to do anything about it. Another listener was to have a more decisive impact: the wife of Justice John Mahoney of the Newfoundland Supreme Court of Appeal.

The next day Hyslop received a call from Justice Mahoney, who asked if Hyslop could verify the allegations of a cover-up at Mount Cashel. Hyslop recalled that Mahoney asked him, 'was there anything sexual involved?' (Harris 1990:263). In reply, Hyslop thought the allegations concerned 'over-zealous strapping', but he was unsure because he had not seen the police reports. According to Hughes (1991:179), 'Hyslop then engaged in a flurry of activity with momentous consequences'. He requested police reports, written in the mid-1970s, related to alleged abuse by the Christian Brothers at Mount Cashel. When reading a report dated 18 December 1975, he learned of 'sexual abuse by at least three Brothers on a horrifying scale ... the amount and type of [which] boggles the mind' (Hughes 1991:180-81). One of the boys interviewed in the original investigation was Shane Earle, who was to become the face of Mount Cashel. Hyslop showed the material to others; and they met with the Minister of Justice, advising her that there 'were strong indications of sexual abuse charges, including confessions having been given by at least two Brothers' (Hughes 1991:185). They concluded that the offences 'were not statute barred and ... we should reopen the investigation' (Hughes 1991:185). Hyslop then wrote to the Chief of Police, saying 'it is clear in my mind that at least one person committed over 100 individual indecent acts on at least 15 boys. Having discovered this horrifying fact on February 14, 1989, what cause of action is open to us?' (Hughes 1991:182). There was an appearance of a 'deal' with the police and the Department of Justice, under pressure by the Christian Brothers, to halt the investigation. The police reopened the investigation. Once the 'discovery' was made by officials, there were media stories and a public victim story in March; these moved the Government in April to announce a Royal Commission of Inquiry into the Response of the Newfoundland Criminal Justice System to Complaints, with the Honourable Samuel Hughes QC as chair.

Meanwhile, during the mid-1980s, offending by priests in the Catholic Archdiocese of St John's was coming to light. Although the priests' offending did not occur at Mount Cashel, their cases contributed to a sense of widespread prevalence of child sexual abuse in St John's.

When Shane Earle learned that an investigation at Mount Cashel was to be reopened, he went to the police. On 16 February 1989, he gave his statement, the first former resident to do so. Publisher and editor-in-chief of the St John's weekly, The Sunday Express, Michael Harris, was following developments after the police investigation was reopened, and on 12 March, he published a strongly worded editorial on the need for an inquiry into 'the deal'. Earle read it and was impressed. He talked with Harris about having his story published in the newspaper and, soon after, his accounts of abuse were published in two 
parts in March 1989. Earle's stories 'went off like a bomb' (Harris 1990:274). Now there was a human face to Mount Cashel. The faces of other survivors were later brought into Canadian homes with television coverage of the Hughes Inquiry from September to December 1989, which was watched on a daily basis by many Newfoundlanders. ${ }^{1}$

Thus, in Mount Cashel, we see allegations of sexual abuse against boys and adolescents by religious men, 'observability' by media stories and wider currents of sexual abuse by priests in the community, and public victim stories. In addition, other political and legal elements triggered a response: allegations of a cover-up by the police and government officials, collusion between government and church authorities, and failed police investigations nearly 15 years earlier. How do these events relate to the Australian cases?

\section{From Mount Cashel to Australia}

Mount Cashel differs from the Australian cases in that it was one institution in one Canadian province, whereas all the Australian cases are of tens to hundreds of institutions statewide or countrywide. However, three Australian states do fit the 'core' case pattern, with immediate attention focused on the failure to protect children and provide care. I turn to one of these: Queensland Institutions.

\section{Queensland Institutions: A core Australian case}

The lead-up to the Forde Inquiry into Abuse of Children in Queensland Institutions was a set of separate, but linked 'storms' that swirled, some for over 10 years, before the Inquiry was announced in August 1998.

The first 'storm', in 1988, concerned allegations that a 14-year old girl had been raped while at the John Oxley Youth Detention Centre. The matter was subject to an internal investigation and, although admissions were made by the offenders, the girl did not wish to report it to the police. The incident was later part of an inquiry into the management of the Centre, conducted by Magistrate Noel Heiner. The Heiner Inquiry began in October 1989, but stopped in February 1989. A new government had been elected in December 1989, and due to concerns that civil action might be taken against the Government for defamation, a Cabinet decision was taken to approve the destruction of documents gathered in the Heiner Inquiry. Since then, many other investigations have been conducted. The matter is variously referred to as 'Shreddergate' and the 'Heiner Affair', and has only recently been settled. ${ }^{12}$ Relatedly, in 1989, there were stories of alleged handcuffing of youth to fences or other parts of the John Oxley Youth Detention Centre. These were verified 10 years later in the Forde Inquiry (Forde 1999:170-74).

The second 'storm' was concern with what was termed 'organised paedophilia'. Such activities had been exposed in several Queensland inquiries in the mid- to late-1980s.

11 According to Harris (1990:303), 'the cable company providing gavel-to-gavel live coverage added a new channel ... to replay each day's testimony in full every night ... 15 per cent of the viewing audience in Newfoundland was tuning in ... on a daily basis'. Mount Cashel had national and international reach, particularly when a two-part television documentary drama, The Boys of St Vincent, was aired in 1992.

12 For many years, the perception had been that documents were shredded to cover up allegations of sexual abuse at the Centre, a belief that was at the centre of Kevin Lindeberg's many petitions and submissions to bring the matter to public attention. However, the Carmody Report (2013) concluded that the Heiner Inquiry (and specifically, the documents shredded) did not relate to child sexual abuse allegations, but rather to allegations by Centre staff against the manager. In January 2014, Lindeberg requested the Crime and Misconduct Commission (CMC) undertake an investigation into why it took over two decades for an official determination that Cabinet shredded the documents. The CMC referred the matter to the Queensland Attorney-General and the Office of the Director of Public Prosecutions (ODPP) (Moore 2014a). The ODPP has decided that it is not in the public interest to prosecute, and the Attorney-General does not wish to investigate further (Moore 2014b). 
However, it received renewed attention with the Wood Royal Commission into the New South Wales Police Service (1995-97), which among other outcomes, exposed sexual and physical abuse of children by teachers, state-employed caregivers, police officers, and members of churches. In May 1996, the Ministers of the Australian Family Services Departments proposed a nationally coordinated strategy, and soon after, Queensland signed on by creating a Children's Commission to address 'concern over paedophile activities' (Children's Commission of Queensland 1997:1). Reading the State Legislative Assembly's Parliamentary Debates for 1 May 1996, one learns that by 'paedophile activities', the member introducing the motion meant sexual abuse of children in all forms (Queensland 1996:863). He recognised that most was intrafamilial, but was particularly concerned with sexual abuse in state-run facilities. Another member declared that 'the moral panic that is now going on in Australian society is justified' (Queensland 1996:867). Here, then, is a legislative assembly member admitting there is a moral panic about child sexual abuse in Australian society! In 1997, there were more media stories of alleged 'cover-ups and other impropriety by police officers and others regarding the investigation of paedophilia ..., both historical and contemporary', which were subject to investigation (Criminal Justice Commission 1998:1).

The third 'storm' was allegations of sexual abuse at St Joseph's Home in Neerkol (west of Rockhampton). When Broken Rites, a support organisation for survivors of Catholic clergy abuse, established a national telephone hotline in 1993, its first callers were former Neerkol residents (Broken Rites Australia 2014). The callers alleged sexual abuse by Reginald Durham when he was a chaplain at the home from 1965-97. When, in 1996, a special Child Abuse Hotline was established by the Queensland Department of Families, Youth and Community Care, it was reported that of the over 400 callers, "nearly 70 per cent ... were adults reporting abuse experienced during their childhood ... while residents in the 1950s and 1960s at St Joseph's Orphanage at Neerkol' (Children's Commission of Queensland 1997: 68-9). Durham was arrested in February 1997 for sexual offences alleged to have taken place, not in the children's home, but in the Rockhampton Parish. He was later charged with offences committed at Neerkol. ${ }^{13}$ A group of former residents, the Neerkol Action Support Group, had organised and began a class action suit (which they won in 1999). They also called for a public inquiry. In August 1998, then Minister for Families, Youth and Community Care, Anna Bligh, appointed a Commission of Inquiry into Abuse of Children in Queensland Institutions.

In Queensland Institutions, the elements that sparked the response and moved the social problem of institutional abuse into the public arena were alleged sexual offences against children in Queensland institutions, which were linked to organised paedophilia in Queensland and other states. There was 'observability' with media stories and a sense of 'widespread prevalence', stemming from the creation of state and national hotlines. There was intense concern, consensus about, and perhaps exaggeration of the problem, although it was termed a 'justified' moral panic. In addition, other key elements were failed police investigations, investigations into police and government cover-ups, and victim group advocacy.

3 Durham was convicted and sentenced for the first set of offences in 1999, but he appealed the convictions of the second set. The Queensland Court of Appeal granted the appeal and ordered a re-trial. Durham then applied to be excused from prosecution because at 83 , he was 'physically and psychologically unfit' to stand trial. His application was accepted (Broken Rites Australia 2014). 


\section{Child Migrants and Stolen Generations: Core-plus Australian cases}

Core-plus-one (Child Migrants) and core-plus-two (Stolen Generations) cases differ from the core cases in that there is a moral claim of a policy or practice wrong against children, which was committed by government or church entities (or both). Further, the policy or practice reaches back many years: from 1900 (on average) for the Stolen Generations and 1912 for Child Migrants. The build-up to these cases included victim public stories of abuse within homes or institutions, but the cases came forward through political campaigns that called attention to the policy or practice wrong of removing children from families and putting them in institutions without parental consent. Campaigns (Child Migrants) and social movement activism (Stolen Generations) were augmented with a large cultural platform of biographies, film, music, and research that strengthened the moral claims.

For Child Migrants, the British and Australian Governments established a policy in 1912 to transport British children to Australia. The rationale pre-World War II was rural development, and after the War, population growth. An estimated 7,000 children were sent to Australia from the UK, and 310 were sent from Malta. Nearly half were taken to Western Australia. In 1986, Margaret Humphreys, at the time a social worker in Nottingham, was approached by a former child migrant and, after learning more about the policy and its effects, she founded the Child Migrants Trust in 1987. She and others campaigned to bring the matter to public attention by calling attention to the financial interests of Catholic religious orders (Christian Brothers and Sisters of Mercy among others), as well as other receiving organisations in the scheme (charitable organisations such as Dr Barnardos Homes and Kingsley Fairbridge Farm Schools).

In August 1987, in Western Australia, a three-page news story in the Western Mail focused on sexual and physical abuse of children in several receiving institutions. With headlines such as 'The nightmare at Bindoon', the stories included interviews with former child migrants (Gill 1997:497). Books began to appear: Lost Children of the Empire in 1989 (from which a documentary of the same title was produced), Empty Cradles in 1994, and Orphans of the Empire in 1997. The Leaving of Liverpool, a documentary drama mini-series, was aired in 1992. Bruce Blyth, a key Western Australian activist, published several books authored by former child migrants; he established a support group and wrote several books himself. In 1994, Blyth led a campaign for a public inquiry in Western Australia on sexual and physical abuse of children in institutions in Bindoon, Castledare, Clontarf, and Tardun (Murray and Rock 2003:151-2). This did not eventuate, but it led in 1996 to the Western Australia Select Committee into Child Migration. Another development was civil litigation against the Christian Brothers, launched in 1994, which resulted in a settlement in May 1996 with 223 former child migrants. In 1997, a committee in the British House of Commons began an inquiry into child migration. The UK Government's response to the Committee's 1998 report 'acknowledged that forced migration was misguided' (Australian Senate Community Affairs References Committee 2001:4), and in 1999, it began to offer travel funds to former child migrants. The year 1998 is the response year for the British Government, but it took two more years for the Australian Government to respond.

Australian Senator for Western Australia, Andrew Murray, recounts the 'forces of luck and timing' that made it possible for him to move the campaign forward (Murray and Rock 2003:149). Murray was a former child migrant: he had been sent to Rhodesia under the Fairbridge Scheme when he was four years old. ${ }^{14}$ He recalled that one day late in 1999, the chauffeur of his Commonwealth car, also a former child migrant, said that Margaret

14 Murray is one of the Commissioners in the Australian Government's Royal Commission into Institutional Responses to Child Sexual Abuse that commenced in 2013 and is ongoing. 
Humphreys was coming to Perth. Murray decided to attend the event at the Western Australian office of the Child Migrants Trust. Then:

\begin{abstract}
$\ldots$ another timely event occurred $\ldots$ [on] the $15^{\text {th }}$ February $2000 \ldots$ [Murray's] office was informed that former child migrants were to hold a peaceful protest outside Parliament House, calling for a judicial inquiry. Luck had it that also present at this protest was the then Leader of the Opposition, Mr Kim Beazley of the Australian Labor Party who had been lobbied hard by former child migrants in their quest to have an inquiry into their issues. He was already well acquainted with the issues. [Murray] approached him and sounded out the possibility of gaining his party's support for a parliamentary inquiry. He agreed unequivocally and in due course, after negotiation, delivered the numbers to get the Senate Community Affairs Reference Committee inquiry up. (Murray and Rock 2003:150)
\end{abstract}

The Senate Inquiry began in 2000, publishing its report the next year. In addition to the sustained campaign by the Child Migrants Trust and by survivor advocacy groups, other media such as books and television series played a significant role in bringing Child Migrants to public attention from as early as the 1980s.

For Stolen Generations, social movement activism challenged policies of forcible child removal at the national level in the 1940s. By 1970, all states and territories had repealed child removal legislation, although removals could still occur under states' child welfare legislation. A key precursor to the announcement of the Human Rights and Equal Opportunity Commission (HREOC) inquiry in 1995 was the Australian Government's Royal Commission into Aboriginal Deaths in Custody (Johnston 1991), which found that ' 43 of the 99 people whose deaths were investigated had been separated from the families in childhood' (HREOC 1997:274). In 1994, the Going Home Conference, held in Darwin, Northern Territory, was attended by representatives from all Australian states and territories. Participants discussed the histories of Indigenous child removal and its continuing impact, and the Conference was a turning point in seeking redress for child removal policies. However, during the decades before the HREOC Inquiry was announced, a significant cultural platform had been building of the 'pain and suffering caused by welfare policies that had taken children away', with biographies, songs, film, and research (see Dow 2008:4). It was the moral claim of the wrong against children and Indigenous people that moved this case into the public arena; physical and sexual abuse was secondary.

\title{
Reflections on responses to institutional abuse
}

This article has sought to conceptualise responses to institutional abuse from the 1980s in Australia, Canada, and other countries by an examination of unfolding events that brought cases to public attention and led to a 'response' by officials, set within a broader societal context of the 'discovery' of child abuse in the 1960s and 1970s. A social problems analysis shows why institutional abuse of children was 'discovered' in the 1980s. Further, I suggested that the 'sexual turn' in the institutional abuse story galvanised responses. Specifically, in the core cases, it was sexual abuse of boys by adult male carers, a 'more disturbing form of abuse' (Corby, Doig and Roberts 2001:83) than harsh physical or discipline regimes. Prevalence and 'observability' of the social problem was enhanced with victim hotlines, public victim stories, and media attention. However, in addition, other political and legal elements featured in the evolution of the core cases: allegations of cover-ups by authorities and failed investigations, which went back 10 years or more. A 'moral panic' analysis is insufficient for understanding responses to institutional abuse in the Canadian and Australian core cases. Although child sexual abuse was a prominent 
concern in the 1980s and reports of institutional abuse increased in the late 1980s and the $1990 \mathrm{~s}$, there is no evidence that estimates of prevalence were exaggerated or that authorities' responses were directed at the wrong people. ${ }^{15}$ Moreover, government and church authorities were motivated to respond for reasons other than sexual abuse of children. They were also responding to allegations of cover-ups by police, government, and church authorities.

In the core-plus cases, the social problem of institutional abuse was secondary to the campaigns and social movement activism to bring policy wrongs against children and groups to light. The core-plus-two cases had been building a cultural platform before the social problem of institutional abuse had been named in the 1980s. In addition to public victim stories in the standard media, the presence of books, films, oral history projects, and other media facilitated awareness by the general public about the policy wrongs.

The typology of core, core-plus-one, and core-plus-two cases is crucial to building empirical knowledge and theoretical analysis of institutional abuse cases. It also helps to build a better comparative framework on what is occurring around the world. For example, all I have read on institutional abuse cases in England and Wales suggests they comprise core cases only. This differs from the Australian and Canadian cases, and some of those noted by Sköld (2013) in Norway and Denmark, where policy wrongs also featured in some cases. Although adult memories of their experiences as children in institutions are often similar, we need to pay attention to why and how the children were placed in institutions.

Until recently, studies of the institutional abuse of children have been carried out using disciplinary approaches from history, sociology, social work, and law. In analysing modes of redress, scholars are now using terms and analysis from restorative justice, therapeutic jurisprudence, and transitional justice. For example, scholars have drawn from restorative justice and therapeutic jurisprudence to identify optimal ways of structuring redress processes and outcomes (see Johnstone 2011 for restorative justice; Graycar and Wangmann 2007 for therapeutic jurisprudence). Transitional justice is briefly considered here.

Those using a transitional justice framework are adapting ideas and practices from one societal context to another. The original context was societies in transition from conflict to peace or from authoritarian to post-authoritarian regimes, and the new context is 'transition in contemporary settled democracies' (McAlinden 2013:211); that is, affluent democratic nations. This is a potentially rich line of analysis, raising new questions about how to frame the problem of institutional abuse of children and how to analyse materials, such as survivors' accounts in public inquiries (for a review of this approach, see Sköld 2013). The value of a transitional justice framework is two-fold. First, analysts can draw connections between justice mechanisms that are used in both contexts: for example, truth commissions in post-conflict societies and public inquiries in settled democracies. Second, analysts can employ a sociopolitical analysis of the potential for change in state-citizen relations or state-church-citizen relations.

Of direct relevance to this article is Jung's (2011) analysis of Indian Residential Schools, a Canadian core-plus-two case. Jung considers the ways in which the redress of a policy wrong (which can be considered an 'historical wrong') has the capacity to reconfigure post-colonial relations. My analysis suggests that transitional justice terms are apt for core-plus-two cases where the institutional abuse of children is part of a broader claim for realigning or transforming state-citizen and majority-minority group relations. However, it

15 One potential exception is Nova Scotia Institutions, where concerns were raised that former residents had falsely accused staff of sexual and physical abuse (see Daly 2014). 
is not relevant to core cases like North Wales, Mount Cashel, and Queensland Institutions, for which responses were to failures of the government (and church and charitable organisations) to care for and protect children.

McAlinden's (2013) analysis of responses to institutional abuse in Ireland departs from my core and core-plus framework. She applies a transitional justice framework to what I consider to be a 'core' case, by arguing that the 'Church-State relationship .... makes the Irish situation noteworthy and unique' (McAlinden 2013:189). The 'regime change' that has been thrown up by Irish inquiries into institutional abuse of children is, she argues, a 'defining moment in Irish political and legal history' because it 'offers a unique opportunity to make a permanent break with the past' from an 'amorphous or undefined' relationship, to one of greater state control of church authority (McAlinden 2013:213). I can think of no other case or country where the potential for significant political change has been facilitated by revelations of and inquiries into a 'core' case of institutional abuse of children. To date, Ireland does seem unique. It also suggests that my analysis of what brings cases to public attention may need to be revised to include the consequences of inquiries for broader political change.

Sköld (2013) also uses a transitional justice framework in reviewing public inquiries into institutional abuse of children in contemporary settled democracies, although she recognises that public inquiries in these contexts are not the same as 'truth-seeking' in post-conflict contexts. She identifies new ways of analysing survivors' accounts and raises important questions about the role and identities of advocacy groups, which precede or are created by inquiries. However, public inquiries are not the only type of response to institutional abuse of children. If we focus solely on them, other responses and modes of redress are overlooked.

The response to historical institutional abuse is a large and multifaceted problem, and scholars must be open to varied theorisations. No one overarching theoretical framework or set of terms can contain it all. It cannot be grasped solely in structural sociopolitical terms, nor in social-psychological analyses of the impact of redress processes and outcomes on survivors. A social problems analysis is relevant (as this article suggests), along with other theorisations: philosophical arguments on corrective justice (Winter 2009), the impact of litigation on organisation change (Lytton 2008), and social constructions of sex and gender in clergy offending (Keenan 2012). If, as Sköld (2013:7) suggests, historical institutional abuse is a new interdisciplinary field, the challenge will be to take that observation seriously by working across different levels of analysis, facets of the problem, and disciplinary and theoretical languages, and to do so with an international frame of reference. 
Appendix and References follow. 


\section{Appendix: Summary of case studies of responses to institutional abuse of children in Canada and Australia.}

\begin{tabular}{|c|c|c|c|c|c|c|c|}
\hline $\begin{array}{l}\text { Case } \\
\text { number } \\
\\
\text { (1) }\end{array}$ & $\begin{array}{l}\text { Short case } \\
\text { name; } \\
\text { type case } \\
\text { (2) }\end{array}$ & $\begin{array}{l}\text { Longer case } \\
\text { name } \\
\text { (most recent); } \\
\text { institution/ } \\
\text { policy/legislation } \\
\text { dates of } \\
\text { operation } \\
\quad \text { (3) }\end{array}$ & Location & $\begin{array}{l}\text { Types of } \\
\text { institutions or } \\
\text { places } \\
\text { (5) }\end{array}$ & $\begin{array}{l}\text { Policy/practice } \\
\text { (if relevant); } \\
\text { types of abuse } \\
\text { (6) }\end{array}$ & $\begin{array}{l}\text { Number of } \\
\text { institutions and } \\
\text { children } \\
\text { affected } \\
\text { (7) }\end{array}$ & $\begin{array}{l}\text { - Response year; } \\
\text { - initial response; } \\
\text { - what sparked the response; and how case } \\
\text { evolved } \\
\text { (8) }\end{array}$ \\
\hline CA1 & $\begin{array}{l}\text { Mount } \\
\text { Cashel } \\
\text { (core) }\end{array}$ & $\begin{array}{l}\text { Mount Cashel } \\
\text { Boys' Home and } \\
\text { Training School, } \\
\text { 1892-1990 }\end{array}$ & $\begin{array}{l}\text { Newfoundland } \\
\text { and Labrador: } \\
\text { St John's }\end{array}$ & $\begin{array}{l}\text { One training } \\
\text { school }\end{array}$ & $\begin{array}{l}\text { Physical and } \\
\text { sexual abuse }\end{array}$ & One school & $\begin{array}{l}\text { - } 1989 \\
\text { - Public inquiry and church inquiry, sparked by } \\
\text { media stories of failed investigations and } \\
\text { cover-ups, and public victim story } \\
\text { - Police investigation and criminal prosecution/ } \\
\text { conviction, civil litigation and settlements }\end{array}$ \\
\hline CA2 & $\begin{array}{l}\text { George } \\
\text { Epoch } \\
\text { (core) }\end{array}$ & $\begin{array}{l}\text { Jesuit Fathers of } \\
\text { Upper Canada } \\
\text { (George Epoch, } \\
\text { a Jesuit priest, } \\
\text { 1946-1986) }\end{array}$ & $\begin{array}{l}\text { Ontario: } \\
\text { Wikwemikong, } \\
\text { Cape Croker, } \\
\text { and Saugeen }\end{array}$ & $\begin{array}{l}\text { Three Aboriginal } \\
\text { reserves }\end{array}$ & Sexual abuse & $\begin{array}{l}\text { One offender in } \\
\text { three communities }\end{array}$ & $\begin{array}{l}\text { - } 1990 \\
\text { - Offending reported to police by a Jesuit priest } \\
4 \text { years after Epoch died, sparked by a victim's } \\
\text { report to a priest in } 1985 \\
\text { - Internal Jesuit investigation and informal } \\
\text { assistance } \\
\text { - Redress scheme, civil litigation and settlements }\end{array}$ \\
\hline CA3 & $\begin{array}{l}\text { St John's } \\
\text { and St } \\
\text { Joseph's } \\
\text { (core) }\end{array}$ & $\begin{array}{l}\text { St John's } \\
\text { Training School } \\
\text { for Boys, } \\
\text { 1895-77; } \\
\text { St Joseph's } \\
\text { Training School } \\
\text { for Boys, } \\
\text { 1933-73 }\end{array}$ & $\begin{array}{l}\text { Ontario: } \\
\text { Uxbridge and } \\
\text { Alfred }\end{array}$ & $\begin{array}{l}\text { Two training } \\
\text { schools }\end{array}$ & $\begin{array}{l}\text { Physical and } \\
\text { sexual abuse }\end{array}$ & Two schools & $\begin{array}{l}\text { - } 1990 \\
\text { - Police investigation and criminal } \\
\text { prosecution/conviction, sparked by media stories } \\
\text { of failed investigations } \\
\text { - Formation of advocacy group } \\
\text { - Redress scheme }\end{array}$ \\
\hline
\end{tabular}




\begin{tabular}{|c|c|c|c|c|c|c|c|}
\hline CA4 & $\begin{array}{l}\text { Grandview } \\
\text { (core) }\end{array}$ & $\begin{array}{l}\text { Grandview } \\
\text { Training School } \\
\text { for Girls, } \\
1933-76\end{array}$ & $\begin{array}{l}\text { Ontario: } \\
\text { Cambridge }\end{array}$ & $\begin{array}{l}\text { One training } \\
\text { school }\end{array}$ & $\begin{array}{l}\text { Physical and } \\
\text { sexual abuse }\end{array}$ & One school & $\begin{array}{l}\text { - } 1991 \\
\text { - Police investigation and criminal prosecution/ } \\
\text { conviction, sparked by victim public stories } \\
\text { - Formation of advocacy group } \\
\text { - Redress scheme }\end{array}$ \\
\hline CA5 & $\begin{array}{l}\text { Nova Scotia } \\
\text { Institutions } \\
\text { (core) }\end{array}$ & $\begin{array}{l}\text { Shelburne Youth } \\
\text { Centre, 1865- } \\
\text { 2004; Nova } \\
\text { Scotia School for } \\
\text { Girls, 1914-85; } \\
\text { Nova Scotia } \\
\text { Youth Training } \\
\text { School, } \\
\text { 1929-97 }\end{array}$ & $\begin{array}{l}\text { Nova Scotia: } \\
\text { Shelburne, Truro, } \\
\text { and Bible Hill }\end{array}$ & $\begin{array}{l}\text { Three training } \\
\text { schools or youth } \\
\text { detention centres }\end{array}$ & $\begin{array}{l}\text { Physical and } \\
\text { sexual abuse }\end{array}$ & $\begin{array}{l}\text { Three schools or } \\
\text { detention centres }\end{array}$ & $\begin{array}{l}\text { - } 1991 \\
\text { Police investigation and criminal prosecution/ } \\
\text { conviction, sparked by victims' reports to } \\
\text { authorities } \\
\text { - Civil claims lodged, redress scheme }\end{array}$ \\
\hline CA6 & $\begin{array}{l}\text { Ontario } \\
\text { Schools for } \\
\text { the Deaf } \\
\text { (core) }\end{array}$ & $\begin{array}{l}\text { Sir James } \\
\text { Whitney School } \\
\text { for the Deaf, } \\
\text { 1870-present; } \\
\text { Ernest C Drury } \\
\text { School for the } \\
\text { Deaf, 1963- } \\
\text { present; Robarts } \\
\text { School for the } \\
\text { Deaf, 1973- } \\
\text { present }\end{array}$ & $\begin{array}{l}\text { Ontario: } \\
\text { Belleville, } \\
\text { Milton, and } \\
\text { London }\end{array}$ & $\begin{array}{l}\text { Three schools for } \\
\text { Deaf and hard-of- } \\
\text { hearing children }\end{array}$ & $\begin{array}{l}\text { Physical and } \\
\text { sexual abuse }\end{array}$ & Three schools & $\begin{array}{l}\text { - } 1991 \\
\text { Police investigation and criminal prosecution/ } \\
\text { conviction, sparked by victims' reports to } \\
\text { authorities } \\
\text { - Redress scheme }\end{array}$ \\
\hline CA7 & $\begin{array}{l}\text { Jericho Hill } \\
\text { (core) }\end{array}$ & $\begin{array}{l}\text { Jericho Hill } \\
\text { Provincial } \\
\text { School, } \\
1922-93\end{array}$ & $\begin{array}{l}\text { British } \\
\text { Columbia: } \\
\text { Vancouver }\end{array}$ & $\begin{array}{l}\text { One school for } \\
\text { Deaf students; } \\
\text { before } 1979 \text {, for } \\
\text { Deaf and blind } \\
\text { students }\end{array}$ & Sexual abuse & One school & $\begin{array}{l}\text { - } 1992 \\
\text { - Ombudsman re-opens case of failed } \\
\text { investigations, sparked by media stories, } \\
\text { previous victims' reports to authorities, and } \\
\text { pressure by victims and families } \\
\text { - Redress scheme and class action settlement } \\
\text { package }\end{array}$ \\
\hline
\end{tabular}




\begin{tabular}{|c|c|c|c|c|c|c|c|}
\hline $\begin{array}{l}\text { Case } \\
\text { number }\end{array}$ & $\begin{array}{l}\text { Short case } \\
\text { name; } \\
\text { type case }\end{array}$ & $\begin{array}{l}\text { Longer case } \\
\text { name } \\
\text { (most recent); } \\
\text { institution/ } \\
\text { policy/legislation } \\
\text { dates of } \\
\text { operation }\end{array}$ & Location & $\begin{array}{l}\text { Types of } \\
\text { institutions or } \\
\text { places }\end{array}$ & $\begin{array}{l}\text { Policy/practice } \\
\text { (if relevant); } \\
\text { types of abuse }\end{array}$ & $\begin{array}{l}\text { Number of } \\
\text { institutions and } \\
\text { children } \\
\text { affected }\end{array}$ & $\begin{array}{l}\text { - Response year; } \\
\text { - initial response; } \\
\text { - what sparked the response; and how case } \\
\text { evolved }\end{array}$ \\
\hline CA8 & $\begin{array}{l}\text { New } \\
\text { Brunswick } \\
\text { Institutions } \\
\text { (core) }\end{array}$ & $\begin{array}{l}\text { New Brunswick } \\
\text { Training School, } \\
\text { 1893-98; } \\
\text { Dr William F } \\
\text { Roberts Hospital } \\
\text { School, unknown } \\
\text { start year to } 1985\end{array}$ & $\begin{array}{l}\text { New Brunswick, } \\
\text { CA: Kingsclear } \\
\text { and Saint John }\end{array}$ & $\begin{array}{l}\text { Three facilities: } \\
\text { training schools } \\
\text { for males } \\
\text { adjudicated } \\
\text { delinquent and } \\
\text { those awaiting } \\
\text { foster placement } \\
\text { (Saint John and } \\
\text { Kingsclear); and } \\
\text { a school for } \\
\text { children with } \\
\text { mental } \\
\text { disabilities }\end{array}$ & Sexual abuse & $\begin{array}{l}\text { Two training } \\
\text { school facilities; } \\
\text { and one for those } \\
\text { with mental } \\
\text { disabilities }\end{array}$ & $\begin{array}{l}\text { - } 1992 \\
\text { - Public inquiry established on same day as } \\
\text { conviction of Toft, self-confessed prolific } \\
\text { offender, sparked by victims' reports to } \\
\text { authorities } \\
\text { - More criminal investigations and } \\
\text { prosecutions/convictions } \\
\text { - Redress scheme } \\
\text { - Investigation of police cover-up }\end{array}$ \\
\hline CA9 & $\begin{array}{l}\text { Alberta } \\
\text { Sterilisation } \\
\text { (core-plus- } \\
\text { one) }\end{array}$ & $\begin{array}{l}\text { Alberta sexual } \\
\text { sterilisation of } \\
\text { those with mental } \\
\text { disabilities, } \\
1928-72 \\
\text { Four feeder } \\
\text { schools: Alberta } \\
\text { Hospital, } \\
\text { Provincial } \\
\text { Training School } \\
\text { in Red Deer, } \\
\text { Alberta Hospital, } \\
\text { and Deerhome }\end{array}$ & $\begin{array}{l}\text { Alberta: Ponoka, } \\
\text { Red Deer, and } \\
\text { Oliver }\end{array}$ & $\begin{array}{l}\text { Four institutions } \\
\text { for those with } \\
\text { mental } \\
\text { disabilities }\end{array}$ & $\begin{array}{l}\text { Policy/practice } \\
\text { (involuntary } \\
\text { sterilisation); } \\
\text { physical and } \\
\text { sexual abuse }\end{array}$ & $\begin{array}{l}\text { Four major } \\
\text { feeder schools; } \\
2,834 \\
\text { sterilisations } \\
\text { carried out of the } \\
4,739 \text { approved } \\
\text { by the Eugenics } \\
\text { Board }\end{array}$ & $\begin{array}{l}\text { - } 1996 \\
\text { - Government response to significant civil } \\
\text { litigation as a consequence of Muir v Alberta } \\
\text { (1996) } 132 \text { DLR }\left(4^{\text {th }}\right) 695 \\
\text { - About } 900 \text { civil settlements }\end{array}$ \\
\hline
\end{tabular}




\begin{tabular}{|c|c|c|c|c|c|c|c|}
\hline CA10 & $\begin{array}{l}\text { Duplessis } \\
\text { Orphans } \\
\text { (core-plus- } \\
\text { one) }\end{array}$ & $\begin{array}{l}\text { Duplessis } \\
\text { Orphans, } \\
1930-65\end{array}$ & Québec & $\begin{array}{l}\text { Nurseries, } \\
\text { orphanages, } \\
\text { training schools, } \\
\text { farm schools, and } \\
\text { psychiatric } \\
\text { institutions }\end{array}$ & $\begin{array}{l}\text { Policy/practice } \\
\text { (false } \\
\text { classification as } \\
\text { mentally } \\
\text { defective or } \\
\text { wrongly placed } \\
\text { in psychiatric } \\
\text { institutions); } \\
\text { physical and } \\
\text { sexual abuse and } \\
\text { medical } \\
\text { experimentation }\end{array}$ & $\begin{array}{l}\text { Minimum } 26 \\
\text { institutions (17 } \\
\text { psychiatric } \\
\text { institutions and } 9 \\
\text { non-psychiatric } \\
\text { institutions), plus } \\
\text { farms); } \\
\text { estimated 5,000 } \\
\text { affected children }\end{array}$ & $\begin{array}{l}\text { - } 1997 \\
\text { Ombudsman investigation, which recommends } \\
\text { redress scheme, sparked by criminal } \\
\text { investigations (but no charges laid) and failed } \\
\text { attempts by advocacy group to litigate } \\
\text { - Advocacy group campaigns; advocacy group } \\
\text { accepts redress scheme offers in } 2001 \text { and } 2003\end{array}$ \\
\hline CA11 & $\begin{array}{l}\text { Indian } \\
\text { Residential } \\
\text { Schools } \\
\text { (core-plus- } \\
\text { two) }\end{array}$ & $\begin{array}{l}\text { Indian } \\
\text { Residential } \\
\text { Schools, under } \\
\text { government } \\
\text { authority, 1867- } \\
\text { 1996; explicit } \\
\text { government } \\
\text { policy of funding } \\
\text { schools for } \\
\text { assimilation, } \\
\text { 1883-1996 }\end{array}$ & $\begin{array}{l}\text { Canada wide } \\
\text { (except Prince } \\
\text { Edward Island, } \\
\text { New Brunswick, } \\
\text { and } \\
\text { Newfoundland } \\
\text { and Labrador) }\end{array}$ & $\begin{array}{l}\text { Training, } \\
\text { boarding, and } \\
\text { residential } \\
\text { schools for male } \\
\text { and female } \\
\text { Aboriginal } \\
\text { children }\end{array}$ & $\begin{array}{l}\text { Policy/practice } \\
\text { (forced } \\
\text { assimilation); } \\
\text { physical and } \\
\text { sexual abuse }\end{array}$ & $\begin{array}{l}139 \text { schools } \\
\text { recognised; } \\
\text { estimated } \\
150,000 \text { affected } \\
\text { children }\end{array}$ & $\begin{array}{l}\text { - } 1996 \\
\text { - Government response to significant civil } \\
\text { litigation } \\
\text { - Advocacy group campaigns and pressure of civil } \\
\text { litigation lead to major civil settlement and large } \\
\text { redress package }\end{array}$ \\
\hline
\end{tabular}




\begin{tabular}{|c|c|c|c|c|c|c|c|}
\hline $\begin{array}{l}\text { Case } \\
\text { number }\end{array}$ & $\begin{array}{l}\text { Short case } \\
\text { name; } \\
\text { type case }\end{array}$ & $\begin{array}{l}\text { Longer case } \\
\text { name } \\
\text { (most recent); } \\
\text { institution/ } \\
\text { policy/legislation } \\
\text { dates of } \\
\text { operation }\end{array}$ & Location & $\begin{array}{l}\text { Types of } \\
\text { institutions or } \\
\text { places }\end{array}$ & $\begin{array}{l}\text { Policy/practice } \\
\text { (if relevant); } \\
\text { types of abuse }\end{array}$ & $\begin{array}{l}\text { Number of } \\
\text { institutions and } \\
\text { children } \\
\text { affected }\end{array}$ & $\begin{array}{l}\text { - Response year; } \\
\text { - initial response; } \\
\text { - what sparked the response; and how case } \\
\text { evolved }\end{array}$ \\
\hline AU1 & $\begin{array}{l}\text { Stolen } \\
\text { Generations } \\
\text { (core-plus- } \\
\text { two) }\end{array}$ & $\begin{array}{l}\text { Separation of } \\
\text { Aboriginal and } \\
\text { Torres Strait } \\
\text { Islander Children } \\
\text { from Their } \\
\text { Families, } \\
\text { 1900-69 } \\
\text { (HREOC inquiry } \\
\text { gives 1910-70 as } \\
\text { indicative } \\
\text { timespan) }\end{array}$ & Australia-wide & $\begin{array}{l}\text { Orphanages, } \\
\text { settlements, } \\
\text { missions, and } \\
\text { training schools; } \\
\text { includes foster or } \\
\text { adoptive family } \\
\text { placements }\end{array}$ & $\begin{array}{l}\text { Policy/practice } \\
\text { (forced } \\
\text { assimilation); } \\
\text { physical and } \\
\text { sexual abuse }\end{array}$ & $\begin{array}{l}\text { Number of } \\
\text { institutions } \\
\text { unknown; } \\
\text { estimated } \\
\text { 20-25,000 } \\
\text { affected children }\end{array}$ & $\begin{array}{l}\text { - } 1995 \\
\text { - Commonwealth public inquiry, sparked by } \\
\text { recognition of the impact of child removal in the } \\
\text { Australian Royal Commission into Aboriginal } \\
\text { Deaths in Custody (1991), advocacy group } \\
\text { campaigns, and Going Home conference (1994) } \\
\text { - Significant cultural platform; services, } \\
\text { memorialisation, and oral history projects }\end{array}$ \\
\hline AU2 & $\begin{array}{l}\text { Queensland } \\
\text { Institutions } \\
\text { (core) }\end{array}$ & $\begin{array}{l}\text { Queensland } \\
\text { Institutions for } \\
\text { Children, } \\
\text { 1865-1999 } \\
\text { (Forde Inquiry } \\
\text { timespan is } \\
\text { 1911-99) }\end{array}$ & Queensland & $\begin{array}{l}\text { Orphanages, } \\
\text { homes, training } \\
\text { schools, and } \\
\text { youth detention } \\
\text { centres; excludes } \\
\text { foster care } \\
\text { placements and } \\
\text { institutions for } \\
\text { children with } \\
\text { disabilities or } \\
\text { acute health } \\
\text { problems }\end{array}$ & $\begin{array}{l}\text { Physical and } \\
\text { sexual abuse and } \\
\text { neglect }\end{array}$ & 159 institutions & $\begin{array}{l}\text { - } 1998 \\
\text { - State public inquiry, sparked by media stories of } \\
\text { paedophilia, police and government cover-ups, } \\
\text { advocacy group pressure, criminal investigation } \\
\text { and prosecution/conviction } \\
\text { - Benefits and services; later, redress scheme }\end{array}$ \\
\hline
\end{tabular}




\begin{tabular}{|c|c|c|c|c|c|c|c|}
\hline AU3 & $\begin{array}{l}\text { Child } \\
\text { Migrants } \\
\text { (core-plus- } \\
\text { one) }\end{array}$ & $\begin{array}{l}\text { Australian } \\
\text { Institutions } \\
\text { receiving Child } \\
\text { Migrants, } \\
1912-70\end{array}$ & $\begin{array}{l}\text { Australia-wide, } \\
\text { except the two } \\
\text { territories }\end{array}$ & $\begin{array}{l}\text { Orphanages, } \\
\text { homes, training } \\
\text { schools, and farm } \\
\text { schools receiving } \\
\text { children sent } \\
\text { from the UK and } \\
\text { Malta }\end{array}$ & $\begin{array}{l}\text { Policy/practice } \\
\text { (forced migration } \\
\text { to Australian } \\
\text { institutions); } \\
\text { physical and } \\
\text { sexual abuse }\end{array}$ & $\begin{array}{l}52 \text { institutions; } \\
\text { estimated 7,000 } \\
\text { affected children, } \\
\text { half pre-World } \\
\text { War II and half } \\
\text { post-World } \\
\text { War II; half sent } \\
\text { to Western } \\
\text { Australia; } 310 \\
\text { sent from Malta }\end{array}$ & $\begin{array}{l}\text { - } 2000 \\
\text { - Commonwealth public inquiry, sparked by } \\
\text { advocacy group campaigns from } 1987 \text { onwards } \\
\text { - Significant cultural platform } \\
\text { - Services and travel benefits, memorialisation, } \\
\text { and oral history and museum projects }\end{array}$ \\
\hline AU4 & $\begin{array}{l}\text { Forgotten } \\
\text { Australians } \\
\text { (core) }\end{array}$ & $\begin{array}{l}\text { Australian } \\
\text { Institutions for } \\
\text { Children, } \\
1895-2000 \\
\text { (Senate Inquiry } \\
\text { timespan is } \\
\text { 1920s-1970) }\end{array}$ & Australia-wide & $\begin{array}{l}\text { Orphanages, } \\
\text { homes, industrial } \\
\text { or training } \\
\text { schools, youth } \\
\text { detention centres, } \\
\text { and homes for } \\
\text { children with } \\
\text { disabilities; } \\
\text { Foster care } \\
\text { considered in } \\
\text { separate Senate } \\
\text { Report (2005) }\end{array}$ & $\begin{array}{l}\text { Physical and } \\
\text { sexual abuse and } \\
\text { neglect }\end{array}$ & $\begin{array}{l}334 \text { institutions; } \\
\text { estimated } \\
500,000 \text { affected } \\
\text { children in } \\
\text { institutional and } \\
\text { out-of-home care }\end{array}$ & $\begin{array}{l}\text { - } 2003 \\
\text { - Commonwealth public inquiry, sparked by } \\
\text { previous inquiries into Stolen Generations and } \\
\text { Child Migrant, and advocacy group assistance } \\
\text { - Services, memorialisation, and oral history and } \\
\text { museum projects }\end{array}$ \\
\hline AU5 & $\begin{array}{l}\text { Tasmanian } \\
\text { Institutions } \\
\text { (core) }\end{array}$ & $\begin{array}{l}\text { Tasmanian } \\
\text { Institutions for } \\
\text { Children, } \\
\text { 1873-1999 }\end{array}$ & Tasmania & $\begin{array}{l}\text { Orphanages, } \\
\text { homes, training } \\
\text { schools, and } \\
\text { youth detention } \\
\text { centres; includes } \\
\text { foster care } \\
\text { placements }\end{array}$ & $\begin{array}{l}\text { Physical and } \\
\text { sexual abuse and } \\
\text { neglect }\end{array}$ & 38 institutions & $\begin{array}{l}\text { - } 2003 \\
\text { - Ombudsman review, sparked by victim public } \\
\text { story } \\
\text { - Redress scheme }\end{array}$ \\
\hline
\end{tabular}




\begin{tabular}{|c|c|c|c|c|c|c|c|}
\hline AU6 & $\begin{array}{l}\text { South } \\
\text { Australian } \\
\text { Institutions } \\
\text { (core) }\end{array}$ & $\begin{array}{l}\text { South Australian } \\
\text { Institutions for } \\
\text { Children and } \\
\text { Indigenous } \\
\text { children in } \\
\text { geographically } \\
\text { remote } \\
\text { communities, } \\
\text { 1895-2004 } \\
\text { (Mullighan } \\
\text { Inquiry timespan } \\
\text { is 1940-2004) }\end{array}$ & South Australia & $\begin{array}{l}\text { Orphanages, } \\
\text { residential and } \\
\text { group care units, } \\
\text { youth detention } \\
\text { centres, homes } \\
\text { for children with } \\
\text { disabilities, and } \\
\text { homes for } \\
\text { Indigenous } \\
\text { children; includes } \\
\text { foster care } \\
\text { placements and } \\
\text { family homes } \\
\text { (latter while on } \\
\text { probation) }\end{array}$ & Sexual abuse & $\begin{array}{l}56 \text { institutions } \\
\text { ( } 19 \text { state and } 37 \\
\text { other types of } \\
\text { state care); foster } \\
\text { or family } \\
\text { placements in } \\
\text { addition }\end{array}$ & $\begin{array}{l}\text { - } 2004 \\
\text { - State public inquiry, sparked by media stories of } \\
\text { abuse in residential care and by church officials } \\
\text { - Services, limited redress scheme }\end{array}$ \\
\hline AU7 & $\begin{array}{l}\text { Tasmanian } \\
\text { Stolen } \\
\text { Generations } \\
\text { (scheme } \\
\text { only; } \\
\text { redress for } \\
\text { core-plus- } \\
\text { two policy) }\end{array}$ & $\begin{array}{l}\text { Stolen } \\
\text { Generations of } \\
\text { Aboriginal } \\
\text { Children Act } \\
2006 \text { (Tas), } \\
1935-75\end{array}$ & Tasmania & $\begin{array}{l}\text { Homes (group, } \\
\text { family, and foster } \\
\text { care), } \\
\text { institutions, } \\
\text { settlements, and } \\
\text { missions }\end{array}$ & $\begin{array}{l}\text { Policy/practice } \\
\text { (forced } \\
\text { assimilation, } \\
\text { includes } \\
\text { biological } \\
\text { children of those } \\
\text { removed if the } \\
\text { individual was } \\
\text { deceased) }\end{array}$ & $\begin{array}{l}\text { Number of } \\
\text { institutions and } \\
\text { affected children } \\
\text { unknown }\end{array}$ & $\begin{array}{l}\text { - } 2006 \\
\text { - Legislation, sparked by recommendation in } \\
\text { Commonwealth inquiry into Stolen Generations } \\
\text { - Redress scheme for policy }\end{array}$ \\
\hline AU8 & $\begin{array}{l}\text { Redress } W A \\
\text { (scheme } \\
\text { only; } \\
\text { redress for } \\
\text { abuse } \\
\text { resulting } \\
\text { from core } \\
\text { and } \\
\text { core-plus } \\
\text { cases) }\end{array}$ & $\begin{array}{l}\text { WA Institutions } \\
\text { for Children, } \\
1886-2006 \\
\text { (start year is } \\
\text { legislation in } \\
\text { respect of } \\
\text { Indigenous } \\
\text { people; end year } \\
\text { is eligibility } \\
\text { criteria for } \\
\text { scheme) }\end{array}$ & $\begin{array}{l}\text { Western } \\
\text { Australia }\end{array}$ & $\begin{array}{l}\text { Orphanages, } \\
\text { homes, training } \\
\text { schools, youth } \\
\text { detention centres; } \\
\text { includes foster } \\
\text { care placements }\end{array}$ & $\begin{array}{l}\text { Physical and } \\
\text { sexual abuse and } \\
\text { neglect }\end{array}$ & 156 institutions & $\begin{array}{l}\text { - } 2007 \\
\text { - Government-stipulated redress scheme, sparked } \\
\text { by recommendations in Commonwealth } \\
\text { inquiries into Stolen Generations, Child } \\
\text { Migrants, and Forgotten Australian }\end{array}$ \\
\hline
\end{tabular}




\section{References}

Arvidsson M (2011) “"A dark chapter in our history”: historical truth commissions on abuse in children's institutions as national memory work', work in progress, University of Örebro, Sweden $<$ http://static.sdu.dk/mediafiles/B/7/0/\%7BB708796C-C252-4AD4-9119-2E7BE952ABA0\% 7DPaper\%20Malin_Arvidsson.pdf>

Australian Senate Community Affairs References Committee (2001) Lost Innocents: Righting the Record, Report on Child Migration, Commonwealth of Australia

Australian Senate Community Affairs References Committee (2004) Forgotten Australians: A Report on Australians Who Experienced Institutional or Out-of-Home Care as Children, Commonwealth of Australia

Badgley R (1984) Report of the Committee on Sexual Offences Against Children and Youths, Government Publications, Supply and Services Canada

Broken Rites Australia (2013) 'Broken Rites supported these victims at a Queensland orphanage', $<$ http://brokenrites.alphalink.com.au/nletter/page3.html>

Carmody T (2013) Queensland Child Protection Commission of Inquiry, 3(e) Report, Queensland Government

Children's Commission of Queensland (1997) Paedophilia in Queensland, Queensland Government

Corby B, Doig A and Roberts V (2001) Public Inquiries into Abuse of Children in Residential Care, Jessica Kingsley Publishers

Criminal Justice Commission, Queensland (1998) Inquiry into Allegations of Misconduct in the Investigation of Paedophilia in Queensland: Kimmins Report, Queensland Government

Csáky C (2009) 'Keeping Children out of Harmful Institutions: Why we should be investing in family-based care', Save the Children Fund <http://www.savethechildren.org.uk/sites/default/ files/docs/Keeping_Children_Out_of_Harmful_Institutions_Final_20.11.09_1.pdf >

Daly K (2014, forthcoming) Redressing Institutional Abuse of Children, Palgrave Macmillan

Davis JE (2005) Accounts of Innocence: Sexual Abuse, Trauma, and the Self, University of Chicago Press

Dow C (2008) 'Sorry: the unfinished business of the Bringing Them Home report', Parliament of Australia <http://www.aph.gov.au/About_Parliament/Parliamentary_Departments/Parliamentary_ Library/pubs/BN/0708/BringingThemHomeReport>

Ferguson H (2007) 'Abused and looked after children as "moral dirt": child abuse and institutional care in historical perspective, Journal of Social Policy 36(1), 123-39

Forde L (1999) Report of the Commission of Inquiry into Abuse of Children in Queensland Institutions, Queensland Government

Garland D (2008) 'On the concept of moral panic', Crime, Media, Culture 4(1), 9-30

Gil DG (1975) 'Unravelling child abuse', American Journal of Orthopsychiatry 45(3), 346-56

Gil E and Baxter K (1979) ‘Abuse of children in institutions', Child Abuse \& Neglect 3, 693-8

Gill A (1997) Orphans of the Empire: The Shocking Story of Child Migration to Australia, Millennium Books 
Gordon L (1988) 'The politics of child sexual abuse: notes from American history', Feminist Review 28 (Spring), 56-64

Graycar R and Wangmann JM (2007) 'Redress packages for institutional child abuse: exploring the Grandview Agreement as a case study in "alternative" dispute resolution', Legal Studies Research Paper No 07/50, University of Sydney Law School

Hacking I (1998) Mad Travelers: Reflections on the Reality of Transient Mental Illnesses, University Press of Virginia

Harris M (1990) Unholy Orders: Tragedy at Mt Cashel, Viking Press

Hoffman BC (1992) The Search for Healing, Reconciliation and the Promise of Prevention: The Recorder's Report Concerning Physical and Sexual Abuse at St. Joseph's and St. John's Training Schools for Boys, Reconciliation Process Implementation Committee, Ontario

Hughes SHS (1991) Royal Commission of Inquiry into the Response of the Newfoundland Criminal Justice System to Complaints (Vols 1-2), Office of the Queen's Printer, Newfoundland ('Hughes Inquiry')

Human Rights and Equal Opportunity Commission (HREOC) (1997) Bringing Them Home: National Inquiry into the Separation of Aboriginal and Torres Strait Islander Children from their Families, Human Rights and Equal Opportunity Commission, Commonwealth of Australia

Johnston E (1991) Royal Commission into Aboriginal Deaths in Custody, Australian Government Printing Service

Johnstone J (2011) 'Consultation on the Development of an RJ Toolkit for survivors of historical institutional abuse', Newcastle University Law School, Newcastle, UK, $<$ http://www.survivorscotland.org.uk/news-and-events/item/consultation-on-the-development-of-a-rjtoolkit-for-survivors-of-historical-institutional-abuse/>

Jung C (2011) 'Canada and the legacy of the Indian Residential Schools: transitional justice for Indigenous people in a nontransitional society' in Arthur P (ed), Identities in Transition: Challenges for Transitional Justice in Divided Societies, Cambridge University Press, 217-50

Keenan M (2012) Child Sexual Abuse and the Catholic Church: Gender, Power, and Organizational Culture, Oxford University Press

Kempe CH, Silverman FN, Steele BF, Droegemueller W and Silver HK (1962) 'The battered-child syndrome', Journal of the American Medical Association 181(1), 17-24

Lytton TD (2008) Holding Bishops Accountable: How Lawsuits Helped the Catholic Church Confront Clergy Sexual Abuse, Harvard University Press

McAlinden A-M (2013) 'An inconvenient truth: barriers to truth recovery in the aftermath of institutional child abuse in Ireland', Legal Studies 33(2), 189-214

Moore T (2014a) 'CMC can't probe Heiner affair delays', Brisbane Times (online), 1 June 2014 $<$ http://www.brisbanetimes.com.au/queensland/cmc-cant-probe-heiner-affair-delays-20140602zrug3.html>

Moore T (2014b) 'No Heiner trial for Goss ministers: Bleijie', Brisbane Times (online), 2 July 2014 $<$ http://www.brisbanetimes.com.au/queensland/no-heiner-trial-for-goss-ministers-bleijie-20140702zstrm.html> 
Murray A and Rock M (2003) 'Child migration schemes to Australia: a dark and hidden chapter of Australia's history revealed', Australian Journal of Social Issues 38(2), 149-67

Parton N (1979) 'The natural history of child abuse: a study in social problem definition', British Journal of Social Work 9(4), 431-51

Penglase J (2005) Orphans of the Living: Growing up in 'Care' in Twentieth-Century Australia, Curtin University Books

Pratt J (2009) 'From abusive families to internet predators?: the rise, retraction and reconfiguration of sexual abuse as a social problem in Canada', Current Sociology 57(1), 69-88

Queensland (1996) Parliamentary Debates, Legislative Assembly, 1 May 1996, 863-74

Rollinson R (2006) Residential Child Care in England 1948-1975: A History and Report, Bath Consultancy $<$ http://www.childabusecommission.com/rpt/pdfs/CICA-VOL5-08A.pdf $>$

Sköld J (2013) 'Historical abuse - a contemporary issue: compiling inquiries into abuse and neglect of children in out-of-home care worldwide', Journal of Scandinavian Studies in Criminology and Crime Prevention 14 (Sup1), 5-23

Stanley N, Manthorpe J and Penhale B (eds) (1999) Institutional Abuse: Perspectives Across the Life Course, Routledge

United States (1979) Senate Hearings on Abuse and Neglect of Children in Institutions, US Government Printing Office

Waterhouse R (2000) Lost in Care: Report of the Tribunal of Inquiry into the Abuse of Children in Care in the Former County Council Areas of Gwynedd and Clwyd since 1974, HC 201, UK Government, The Stationery Office

Webster R (2005) The Secret of Bryn Estyn: The Making of a Modern Witch Hunt, Orwell Press

Winter S (2009) ‘Australia's Ex Gratia Redress', Australian Indigenous Law Review 13(1), 49-61 